\title{
Digital Kelsoism: \\ Employee Stock Ownership as a Pattern for the Online Economy
}

\author{
Nathan Schneider \\ University of Colorado Boulder \\ In Beyond 2020: Reimagining the Governance of Work and \\ Employment in a Rapidly Changing World, ed. Dionne Pohler (Cornell \\ University Press, 2020)
}

Louis Kelso's Employee Stock Ownership Plan (ESOP) became a feature of US employment law in 1974, and since then it has enabled millions of people to benefit from an ownership stake in their workplaces. But Kelso, together with his collaborator Patricia Hetter Kelso, envisioned much more than the ESOP. They proposed a series of similarly structured plans that involved leveraged financing for broad-based ownership among stakeholders beyond just the employment relationship, situated in a distinct theory of political economy.

This essay argues that Kelso and Kelso's proposals deserve reconsideration in an age of the increasingly dominant online economy. Although first envisioned in another time, they anticipate frequent anxieties and ambitions surrounding digital networks, from gig work and big data to universal basic income. The proposals also come with financing mechanisms and policy tools that, as with the ESOP, could make them scalable and self-perpetuating. The essay reconsiders several Kelsoist strategies in light of the digital economy and addresses concerns from critical research on the ESOP legacy.

The author gratefully acknowledges input from David Ellerman and Christopher Mackin, as well as support through a Louis O. Kelso Fellowship from the Rutgers University School of Management and Labor Relations. 
In the early 1960s, Detroit autoworker and unionist James Boggs extrapolated theory from the rise of the machines that he experienced firsthand from the factory floor:

automation is that stage of production which carries the contradictions of capitalism to their furthest extreme, creating and sharpening inside capitalist society the conflicts, antagonisms, clashes between people that make for social progress and the inevitable struggle that goes with it. (Boggs 1963)

Boggs regarded himself an enemy of capitalism. Yet his analysis of the problem was not unlike that found in The Capitalist Manifesto (1958), published a few years earlier by a little-known San Francisco lawyer, Louis O. Kelso, and the famous philosophy professor Mortimer J. Adler. Its underlying vision was mainly Kelso's, and at its root was the conundrum of automated productivity that diminished the leverage of labor. In a 197560 Minutes interview, Kelso told Mike Wallace:

the scientist, the engineer, and the manager is hell-bent on destroying employment. That's how he measures his success: how much employment he can destroy.

WALLACE: By putting in machines?

KELSO: By substituting machines for men, right. (Speiser 1977, 9)

While Boggs sought a workers' revolution against capitalism, Kelso wanted to save capitalism by transforming it, by making capitalists out of the workers. And to an uncommon degree - but far short of his aims - Kelso succeeded. He devised the Employee Stock Ownership Plan, or ESOP, in the mid-1950s, then arranged its passage into US employee-benefits law starting in the mid1970s. By the time of his death in 1991, the ESOP had enabled on the order of 10 million US employees to earn not only wages but capital income from the companies where they worked (Kelso and Kelso 1986). Today, ESOP participants number around 14 million employees in over 7,000 companies (National Center for Employee Ownership n.d.).

Both Boggs and Kelso should be regarded today as prescient. They identified ways in which technology was poised to undermine both the order of industrial production and the forms of worker solidarity that might counteract its abuses. Simply put, as worker labor becomes more peripheral to production, and as 
workers lose their ability to demand a share of the surplus, ever more spoils go to the small class of capitalists.

Boggs offered a distinctive yet nonetheless familiar Marxist synthesis in response to the impending crisis. Kelso's broader outlook has not been widely remembered, however, despite the widespread adoption of the ESOP. Together with his collaborator (and eventual spouse) Patricia Hetter Kelso, he had in mind much more than the ESOP. They proposed a series of similarly structured plans that involved leveraged financing for broad-based ownership among stakeholders beyond just the employment relationship, situated in a distinct theory of political economy.

This essay argues that Kelso and Kelso's proposals deserve reconsideration in an age of an increasingly dominant online economy. Although first envisioned in another time, they anticipate frequent anxieties and ambitions surrounding digital networks, from gig work and big data to universal basic income. Kelsoism, as I will call their body of work, appears to have accurately predicted the growing share of wealth in advanced economies since the 1970s accruing to capital, as opposed to labor (Karabarbounis and Neiman 2013), together with the concurrent rise in the inequality and concentration of wealth (Alvaredo et al. 2013). The proposals also come with financing mechanisms and policy tools that, as with the ESOP, could make them scalable and self-perpetuating, especially if unions and other forms of organized solidarity participate. The essay reconsiders several Kelsoist strategies in light of the digital economy and raises concerns from critical research on the ESOP legacy.

First, I outline the contours of Kelsoism and the career of Louis Kelso, including both the horizon it sets forth and the critiques that have been leveled at his legacy. Next I consider applications of Kelsoist proposals beyond the ESOP to challenges that have arisen in the platform economy. Following this, I offer reflections on Kelsoism as a practical political strategy. I conclude with more speculative reflections on the intertwining of democratic ownership and democratic citizenship.

For one familiar with Kelsoism, its current political absence is conspicuous. Andrew Yang, a long-shot but Internet-viral 2020 Democratic presidential candidate, ran as a venture capitalist promoting universal basic income through a value-added tax - a salve for the capitalism he believed in through non-labor income. Yet his campaign manifesto (2018) makes no mention of Louis Kelso or the practical proposals Kelsoism offers toward similar ends. This omission is common among other recent basic-income writings as 
well (e.g., Van Parijs and Vanderborght 2017). Even venture capitalists like Yang turn to redistributive taxation, rather than the mechanisms of capital ownership to which they owe their own wealth, as a means of generating wealth for others.

One need not identify as a venture capitalist, or a capitalist at all, ${ }^{1}$ to find insight in a body of work that offers unusually well-tested strategies to reorient the circulations of wealth downward and reduce more people's dependence on the drudgery of labor. The fresh challenges and stark inequalities of the online economy make the Kelsoist proposals more timely than when they were first proposed.

\section{Kelsoism in brief}

To the extent that Louis Kelso's name is remembered today-almost thirty years since his death, in 1991-it is in the context of the Employee Stock Ownership Plan. The ESOP's impact on the livelihoods of millions of families alone makes it a remarkable feat of legal and policy innovation. Yet his early writings on political economy (e.g., Kelso and Adler 1958) barely mention workers owning stock in their companies, and his final book (Kelso and Kelso 1986) downplays his best-known invention. Its subtitle is Extending the ESOP Revolution; the extension it refers to is a vision for economic democracy that eclipses the employment relation rather than further entrenching it.

Kelso's retellings of his intellectual Bildungsroman (Speiser 1977; Kelso 1984; Kelso and Kelso 1986, 1989) went something like this: As a teenager from a poor family outside Denver, and then as a finance and law student at the University of Colorado, he witnessed the ravages of the Great Depression and sought to understand their cause. He devoured Karl Marx's analysis of capitalism but came out siding with capital, not labor as such. (Milton Friedman, after calling Kelsoism "crackpot," described it as "Marx stood on its head" (Unknown author 1970).) New Deal employment programs seemed to him arbitrary and wasteful, producing jobs for the sake of jobs-later he would call them "boondoggle jobs" (Kelso and Kelso 1982)-rather than going to the root of the problem in the allocations of capital. During World War II, while assigned to Panama as an intelligence officer, Kelso composed a manuscript called The Fallacy of Full Employment. But upon the war's end, Congress unknowingly set out to refute him with the Employment Act of 1946, which fixed jobs as the bedrock of economic policy. Seeing the tide

\footnotetext{
${ }^{1} \mathrm{I}$ do not.
} 
turning against him, Kelso put the manuscript in his closet and set about becoming a successful corporate lawyer. That is just what he had done by the time he began attending Great Books courses under Mortimer Adler in 1951 and became the philosopher's attorney. Adler convinced him to edit down the manuscript into The Capitalist Manifesto, which became a bestseller, meriting even a lengthy and critical review in the official Soviet newspaper Pravda (Speiser 1977, 136).

Kelsoism is fairly straightforward to systematize because, over the course of Louis Kelso's adult life, it remained largely consistent. (It nevertheless went by various names, including "two-factor theory," "binary economics," and "democratic capitalism.") The underlying mantra is that there are two distinct factors of production - labor and capital - and capital is the preferable half (Kelso and Kelso 1986; Ashford 1990-1991). When capital investments automate production, it doesn't make labor more productive, as the economic jargon tends to claim; it makes capital more dominant and labor less essential. If capital mainly circulates among only a small subset of the population, a growing mass of people become ever more extraneous to the economy. The task of economic policy, therefore, should be to help convert "labor workers" to "capital workers"- to ensure more people remain economically relevant by holding and deriving income from capital ownership as labor income dwindles. Kelsoism regards this as better than more jobs, since capital income liberates time for activities other than working for money. It also contends that a diffusely capitalist economy would be more efficient and depression-proof.

Kelso stressed that his view was not just a matter of economics or business but political economy. He understood democracy as resting on the dual legs of economic and political power. Each must be distributed among all citizens. Without "universal capitalism," economic oligarchy would corrode any democratic mechanisms in political life. Like Abraham Lincoln's Homestead Act, which granted Western land to landless settlers, Kelso sought to raise capital among those who lacked it, believing that the future of democratic society depended on so doing (Moyers 1990).

By the lights of the economic profession, Kelsoism has been mainly ignored or dismissed as an eccentricity. The one prominent contemporary economist who engaged with Kelso at length, Paul Samuelson, cited the stability of labor's share of income to refute Kelso's claims (Speiser 1977; Samuelson 1977); that was in the 1970s, however, just around the time that the labor-share began declining, as it has consistently since (Karabarbounis and Neiman 
2013). Political philosophy does not offer a school of thought that precisely maps to Kelsoism either. If anything, it most closely resembles the dictates of distributism (e.g., Novak 1984), a Catholic-aligned vision that advocates widespread property and capital ownership, following the teachings of Pope Leo XIII. Among more recent currents, Kelsoism bears some kinship with the accelerationists, who seek to accelerate capitalist logics toward a utopia of automation and universal basic income (e.g., Srnicek and Williams 2015). But none of these schools fully captures Kelso's eccentricity—nor his pragmatism.

For much of his career, Kelso was a partner at the San Francisco firm Brobeck, Phleger \& Harrison, which would later play a leading role in the rise of Silicon Valley until the firm's bankruptcy in the dot-com bubble. There he brokered major corporate and real estate deals, witnessing firsthand how the capitalist elite does business. In the words of fellow lawyer Stuart M. Speiser, author of the only book-scale assessment of Kelso's legacy (1977), "He couldn't help but notice that the wealthy, whether corporations or individuals, had a habit of acquiring more capital by letting it pay for itself" (p. 131). The basic, persistent impulse of Kelso's proposals was to equip the under-capitalized masses with the means of capital acquisition and management that the rich already enjoyed, and to do so without undue exposure to risk or expectations of expertise.

\section{Capital diffusions: Kelsoist plans}

Each "plan" that Kelso and his collaborators proposed followed a pattern: finance the acquisition of capital on the expectation of future earnings; use the fresh capitalization to fund growth; ensure the earnings of capital from that growth become non-labor income for what he called the "new capitalists" (Kelso and Adler 1961). He called for government to form an entity called the Capital Diffusion Insurance (or, later, Reinsurance) Corporation, which would provide federal backing to spur such transactions. Its purpose would be "debunking the savings mystique" (Kelso and Kelso 1986, 113)-replacing the expectation that a borrower must have existing wealth with a system of commercial insurance-based finance for capital investments. He also hoped that unions would pivot from mainly brokering labor arrangements to organizing capital work, so as "to minimize the toil and maximize the earnings and leisure of each member" (152). 


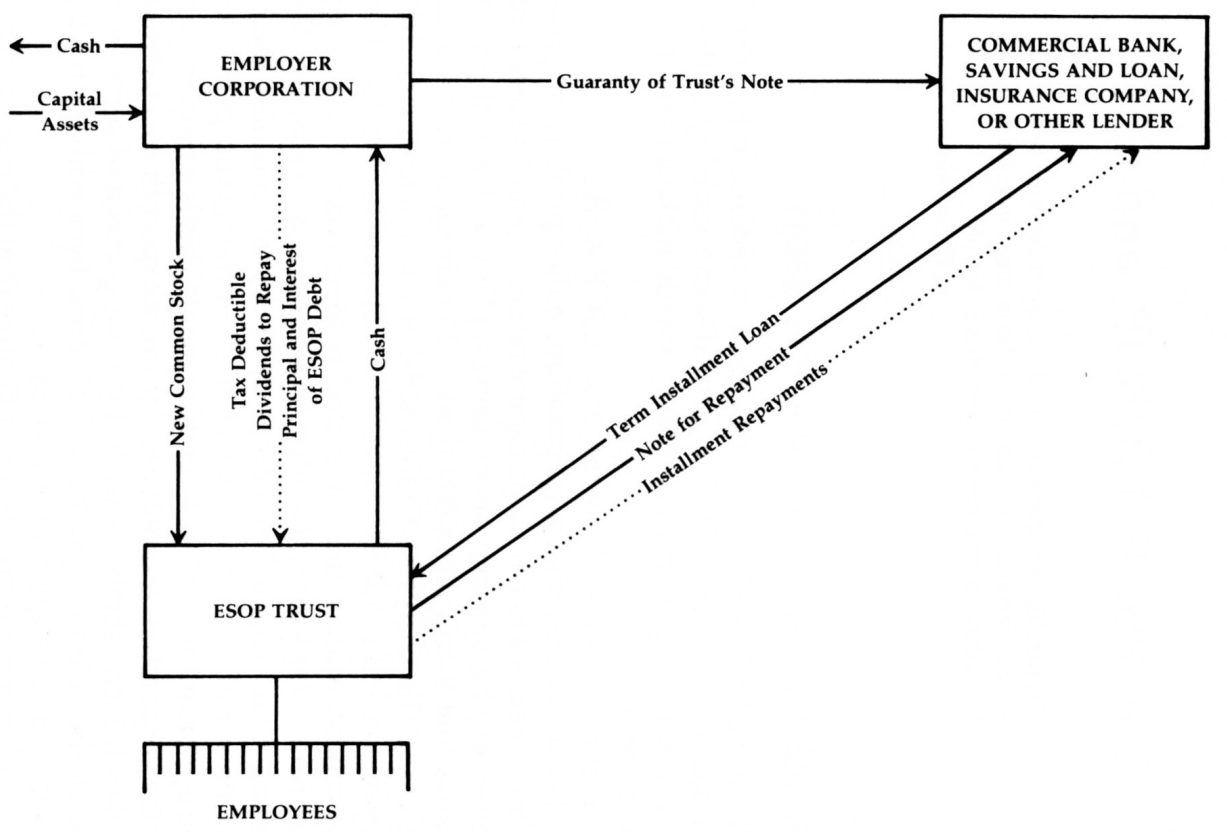

Figure 1: Employee Stock Ownership Plan (ESOP); all figures via Kelso and Kelso (1986), reproduced with permission

Kelso's early books focused on a "financed-capitalist plan," which applied the pattern to acquisition of public stocks (Kelso and Adler 1958, 1961). Employees co-owning their place of employment was a matter of only brief consideration. By that time, however, he was already experimenting with forming ESOPs, beginning with the conversion of Peninsula Newspapers, a Bay Area media chain, to employee ownership in 1956. (See a schematic in Figure 1.) These experiments proliferated to the point that, in 1970, he left Brobeck to create a firm of his own and an investment bank, both specializing in implementing Kelsoist strategies. After repeated entreaties to Republican politicians - including Barry Goldwater, Gerald Ford, and Richard Nixon-Kelso found his policy champion in a centrist Louisiana Democrat, Senator Russell Long (Speiser 1977; Levin 1985-1986). Long became a convinced Kelsoist but didn't see a political opening for the likes of a Capital Diffusion Insurance Corporation. Instead, starting in 1974, he brokered the inclusion of the ESOP as a "qualified" retirement plan in the Employee Retirement Income Security Act, which included favorable tax treatment for a company's contributions to an ESOP, its lender's interest payments, and its capital gains. This was not all that Kelso had hoped 
for, but it was a start, and ESOPs began proliferating across the economy. He regarded the ESOP, at least, as "the Trojan Horse for democratizing American capitalism" (Kelso and Kelso 1986, 53).

The most mature set of Kelsoist "financing tools for democratizing capitalism" appears in Kelso and Kelso (1986) ${ }^{2}$ following an epigraph from William Blake: "He who would do good to another / must do it in Minute Particulars." The plans described there are summarized in Table 1.

\begin{tabular}{|c|c|}
\hline Plan & Summary \\
\hline $\begin{array}{l}\text { Employee Stock Ownership Plan } \\
\text { (ESOP) }\end{array}$ & $\begin{array}{l}\text { Employees borrow to buy stock in } \\
\text { their employer }\end{array}$ \\
\hline $\begin{array}{l}\text { Mutual Stock Ownership Plan } \\
\text { (MUSOP) }\end{array}$ & $\begin{array}{l}\text { Employees or community members } \\
\text { borrow to buy stock in a diversified } \\
\text { pool of smaller companies }\end{array}$ \\
\hline $\begin{array}{l}\text { Consumer Stock Ownership Plan } \\
\text { (CSOP) }\end{array}$ & $\begin{array}{l}\text { Habitual customers of a business } \\
\text { borrow to gain an ownership stake } \\
\text { in it }\end{array}$ \\
\hline $\begin{array}{l}\text { General Stock Ownership Plan } \\
\text { (GSOP) }\end{array}$ & $\begin{array}{l}\text { Eligible people borrow to finance } \\
\text { and co-own public works projects }\end{array}$ \\
\hline $\begin{array}{l}\text { Individual Capital Ownership Plan } \\
\text { (ICOP) }\end{array}$ & $\begin{array}{l}\text { Eligible people borrow to invest in } \\
\text { eligible businesses }\end{array}$ \\
\hline $\begin{array}{l}\text { Commercial Capital Ownership } \\
\text { Plan (COMCOP) }\end{array}$ & $\begin{array}{l}\text { Eligible people borrow to invest in } \\
\text { commercial real estate }\end{array}$ \\
\hline $\begin{array}{l}\text { Public Capital Ownership Plan } \\
\text { (PUBCOP) }\end{array}$ & $\begin{array}{l}\text { Eligible people borrow to privatize } \\
\text { and own government assets }\end{array}$ \\
\hline $\begin{array}{l}\text { Residential Capital Ownership Plan } \\
\text { (RECOP) }\end{array}$ & $\begin{array}{l}\text { Residents borrow to purchase a } \\
\text { home through low-cost commercial } \\
\text { finance }\end{array}$ \\
\hline
\end{tabular}

Table 1: Kelsoist plans as presented in Kelso and Kelso (1986)

Each of these serves a common purpose: to finance economic growth while enabling widespread capital ownership. In several cases, the capital owners would have a participatory relationship with their assets. In all but the last case, as with the ESOP, a trust entity mediates ownership on the

\footnotetext{
${ }^{2}$ Hockett (2007) presents a comparable listing of such mechanisms with several interesting differences. He also usefully links his proposals to existing US policies supporting housing and education lending.
} 
beneficiaries' behalf, simplifying finance and governance. These plans might also be combined; for instance, an electric utility might have a CSOP for its customers and an ESOP for its employees, while financing new transmission lines through a GSOP made up of people in the community that the lines will serve. This kind of multi-stakeholder approach to utility ownership could be especially well-suited to the multi-stakeholder nature of Internet platforms.

\section{Critiques of actually existing Kelsoism}

The Kelsoist proposals might seem far more fanciful were it not for the actually existing example, the ESOP. ESOPs have become widespread and are generally functional. They appear to exhibit productivity gains, especially when paired with participatory governance, and reduce the likelihood of layoffs (Blasi, Kruse, and Freeman 2018); employee profit-sharing may also have beneficial macroeconomic effects (Weitzman 1984). All this testifies to the promise of further "SOPs," were we to give them a chance. Yet in the minds of many, Kelsoism has become coterminous not only with the ESOP idea but with the specific implementation of it in US employment and tax law. As a result, the critical literature on Kelso's legacy mainly concerns the ESOP as such. ${ }^{3}$ These critiques still offer lessons for any broader application of Kelsoist proposals.

One notorious critique of the ESOP came in a paragraph from the Seventh Circuit appeals court decision of Judge Richard Posner (2006) regarding the disastrous United Airlines ESOP-involved bankruptcy. "The time may have come to rethink the concept of an ESOP," he suggested, citing in particular the lack of diversification that, in the case of United, doomed the ESOP participants' retirement accounts. (ESOPs frequently exist alongside diversified accounts such as a 401k.) Posner went on, "The tax advantages of the form do not represent a social benefit, but merely a shift of tax burdens to other taxpayers." He dismissed the economic logic that employee ownership might confer productivity benefits and referred to the challenge of managing an ESOP as a retirement plan as "awkward." The one advantage he could think of was that ESOPs might depress interest in unionization (cf. Levin 1985-1986; Posner 2007).

From the inverse perspective of concern for worker power, David Ellerman (1985) compares the ESOP with the worker cooperative and regards the

\footnotetext{
${ }^{3}$ One exception, Speiser (1977), assails Kelso's "two-factor" economic theory mainly on the grounds that the rhetoric of devaluing labor undermined the proposals' political prospects.
} 
former as "second-class ownership without control," an inferior kind of democracy that dwells only in property rights, not "personal rights." Paradoxically, adds Michael Murphy (2005), the productivity benefits ascribed to ESOPs seem to depend on the cultivation of participatory workplaces - an add-on to the model not required by or provided for in ESOP law. Murphy further points out that the stock-repurchase obligation for retiring employees can represent a crippling constraint.

Most recently, Jedidiah Kroncke (2018) compiles several decades of such assessments. He emphasizes how the ESOP's design "completely divorced worker participation from ownership," making it most inviting for purposes like management capture and accruing tax subsidies for businesses that are already successful. When the subsidies abated after 1989, so did new ESOP formation. He concludes it is "a legal form that ultimately led to more problems and abuses than it transformed any particular workplace or assuaged growing inequality." While many advocates and ESOP participants would contest this charge, it deserves to be taken seriously.

Many of the concerns about ESOPs, again, fall more upon the particular circumstances of the model's implementation in US employment law than on the Kelsoist agenda more broadly. Kelso himself hoped that employee ownership would have a policy vehicle more maneuverable than a retirement plan. A broader Kelsoism might further address Posner's concern about diversification by enabling people to participate simultaneously in several distinct kinds of SOPs. The ESOP experience also suggests that the greatest benefits arise when ownership occurs in tandem with participatory management, as Kelso's vision of the capital worker implies; future iterations might more intentionally link ownership and governance. Labor unions have meanwhile largely rejected ESOPs as antithetical to their role of forcing concessions from capital (McElrath and Rowan 1992; Cramton, Mehran, and Tracy 2008), but - this being the subject of the final section of his final book, in fact-Kelso held out hope that unions might find a powerful "new role" as asset stewards for the new democratic capitalists (Kelso and Kelso 1986).

The critiques that most directly challenge orthodox Kelsoism are those that raise the specter of commodification. As Ellerman puts it, if the goal is to advance democratic society, "worker capitalism" should be traded for "worker democracy." It is not enough, the claim goes, to turn the firm into a more widely accessible commodity; rather, firms should evolve into a kind of commons, able to seek not just financial profit but social purpose. Kelsoism's faith in broad-based commodification stands guilty as charged, in my view, 
although Kelsoist capitalism turns out to be a moving target.

\section{Plans for a digital Kelsoism}

The jacket copy for The Capitalist Manifesto (1958) begins with words that, in the years since the 2008 financial crisis, would be hard to imagine arranged in this sort of way:

When you read this book, you must be prepared for a shockparticularly if you are among the millions of Americans who feel complacent about the material well-being that now prevails in this country. The Capitalist Manifesto will compel you to examine, reconsider and question many dangerous economic factors and political tendencies you have accepted as inevitable - and will show you how you can do something about them.

The publisher, that is, understood Kelso and Adler's argument to stand on a premise of an economy in danger, a premise not likely to correspond with the intuitions of its intended readership. Putting aside the widespread exclusions along lines of race, gender, and class from the "well-being" circa the late 1950s Pax Americana, the social contracts of industrial capitalism were on the up-and-up; lifelong, unionized work was attainable for many, capable of supporting a nuclear family and its growing armada of consumer accessories. Kelso's choice to spur his revolution with the ESOP reflected that reality; employment was the typical family's most reliable economic relationship.

This condition has changed. The dust-jackets of economic bestsellers in the United States now tend to presume a shared mood of crisis, not upward mobility. Even what appear to be the most up-and-coming quarter of the economy, the online platforms, announce their successes as "disruption," prompting anxious discussions in philanthropy, academia, and public media about the yet-unknown "future of work." In such a context, the postworkist tendencies of Kelsoism might have particular usefulness. In a time of transient, unstable work, there can be less pretense that the ESOP alone will be sufficient; the eye of a digital Kelsoist drifts toward other possible plans before that one. And these plans offer salves for troubles that lie beyond matters of stock dividends alone. Ownership, that is, can be a mechanism for governance and accountability, not just value capture.

By the digital in "digital Kelsoism," I refer to the ever-greater digitization of economic and social life. This process provokes concerns about a rising, global "precariat" class that lacks the protections of a robust social contract 
(Standing 2011), together with the specters of automation (Brynjolfsson and McAfee 2016), labor exploitation (Scholz 2017), and corporate consolidation (Khan 2017). Some claim data has become a new form of labor (Posner and Weyl 2018), except rather than through regulated employment contracts, companies acquire it by means of surveillance (Pasquale 2015; Zuboff 2019), putting new guises on old kinds of marginalization (Eubanks 2018; Noble 2018). Changes in the real economy may not have lived up to the platforms' hype - the real extent of gig work, for one thing, appears less than boosters claim (Mishel 2018) - but the hype alone has begun communicating and instilling certain cravings for the better parts of what the existing platform disruptions dubiously promise: a more flexible, creative economy of selfdetermination, sharing, and low-cost services (Schor 2014; Srnicek and Williams 2015).

This section presents three adaptations of Kelsoist proposals for the conditions of the online platform economy - one focused on the identity category of users, one for the category of rank-and-file investors, and one for a universal entitlement in a world where labor contributes and receives a declining share of the economic pie. Each remains mainly speculative at present and, like the ESOP, would likely require regulatory support in order to thrive. Yet each builds on the ESOP's legacy enough that it may be unexpectedly feasible, both economically and politically.

\section{User work}

The term "user" in the context of platforms is an ambiguous one. People who hold accounts on platforms play a variety of roles: consumer, worker, spectator, producer, investor, expert, organizer, moderator, and more. None of these roles, however, is quite what it seems. In the realm of what Shoshana Zuboff (2019) calls "surveillance capitalism," any of these roles contributes "behavioral surplus" that platforms collect as data in order to produce the market capture and behavior modifications that are the platforms' most lucrative product. A user's perceived role is thus alienated from realities an economic analysis might reveal. Pairing user-ship with capital ownership could lessen that alienation and stem its potential abuses. 


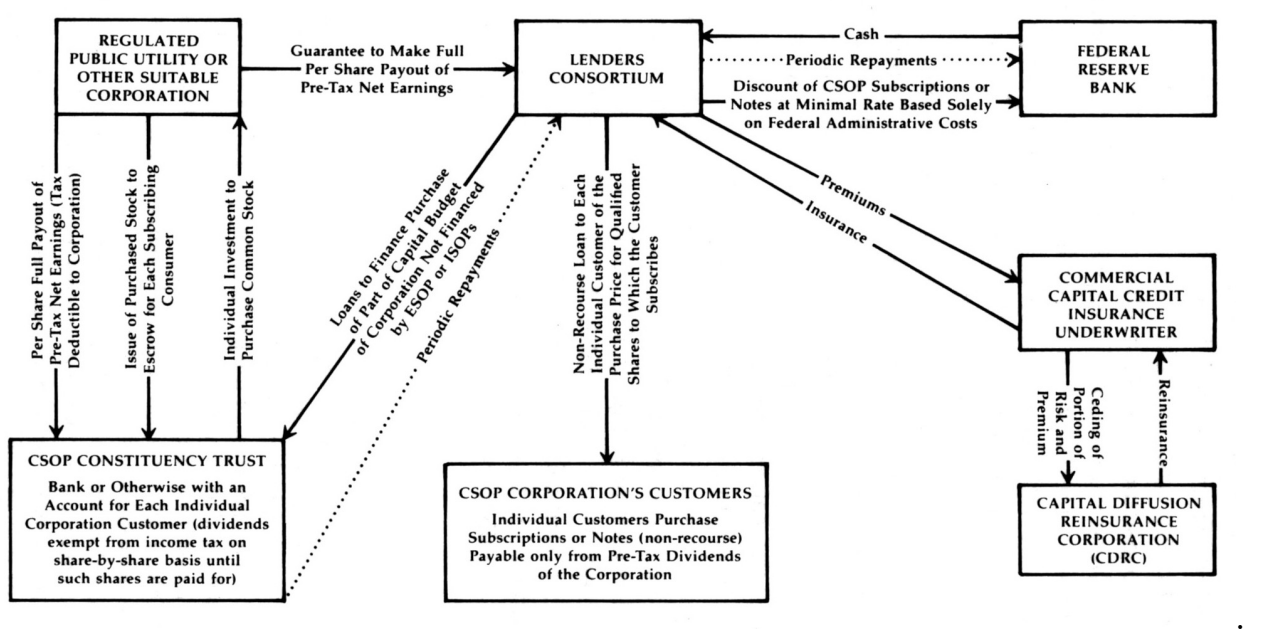

Figure 2: Consumer Stock Ownership Plan (CSOP) in Kelso and Kelso (1986)

Louis Kelso's second most well-developed proposal was the consumer stock ownership plan, or CSOP (Figure 2), which he tested with a California company called Valley Nitrogen, beginning in 1957. Valley Nitrogen was a fertilizer producer financed through a trust established on behalf of its farmer-customers, much as an ESOP would be financed through an employee trust. Kelso and Kelso (1986) envision the CSOP as best suited for

public utilities and of other business corporations having monopolistic or oligopolistic consumer relationships, or having a substantial body of steady consumers who purchase its goods or services in large quantities year after year.

These might include, in the Kelsos' view, power companies, neighborhood grocery stores, department stores, gas stations, and the like - the hard-toavoid staples of consumer life. A new set of hard-to-avoid staples have arisen in our digital lives. CSOPs might, for instance, finance broadband expansion and improvement in underserved areas, as cooperative and municipal models have successfully done (Talbot, Hessekiel, and Kehl 2017). CSOPs could use capital gains to supplement the incomes of platform producers, such as ride-share drivers, home-sharing hosts, and retail-platform sellers; platform companies such as Airbnb, Lyft, and Uber have already sought the legal license to distribute stock to such users (Schneider 2020). In cases where the user relationship is primarily non-monetary, such as among social-media platforms, a CSOP could be a vehicle for leveraging voting rights to counteract 
pressures for excessive data extraction. The CSOP might thus function as a kind of users' union, representing their economic and privacy interests in the boardroom.

Why would a company invite such a creature into its midst? ESOPs are arrangements that companies adopt voluntarily and organize on behalf of their workforce. Trustee governance tends to be pliable to board or management interests. In the same way, companies could see benefits in better aligning the incentives of users and investor-owners, which appears to be why Airbnb, Lyft, and Uber want to make user stock distributions. The Google-affiliated Sidewalk Labs project has proposed a semi-independent "civic data trust" to manage the data its "smart city" sensors collect (McDonald 2019). But the arrangement need not necessarily be so cordial. Independently organized user CSOPs could engage in leveraged hostile takeovers. A reinvigorated antitrust regime could also require user ownership as a check against abuses by monopolistic platforms (Vaheesan and Schneider 2019). Threats of external regulation surrounding certain behaviors could provoke platforms to adopt CSOPs as a sort of self-regulation. Regardless of the motivation, making the CSOP model available and conducive to financing could help ensure that the value users contribute to platforms, and the users' human rights, are better accounted for in the workings of ever-more powerful platforms.

David Ellerman (2015) has raised the concern that the economics would become difficult in a "SOP" not able to rely on tax-advantaged employee compensation for its loan repayment, as ESOPs have tended to do-rather than relying on dividends, as Kelso hoped. This concern is especially applicable in the online economy, as many startups avoid dividend distributions for long periods in order to invest in growth. User CSOPs might need to ensure that companies can regard equity distributions as tax-advantaged compensation; in other cases, users could hold a non-dilutive class of shares with special governance rights, issued at no cost. User ownership need not pantomime all the features of investor ownership.

\section{Capital work}

One outgrowth of Internet platforms has been to render more accessible the activities and subjectivities of what Kelso called capital work. For instance, online investing platforms promise to enable "anyone" to partake in the trading of stocks and other securities, informed by an informational onslaught of tickers, graphs, and investing-gossip blogs. Crowdfunding platforms enable users to bet on and "back" new startups, products, and public goods; in some 
cases, these can involve direct equity offerings for non-accredited investors. More recently, the advent of cryptocurrencies has birthed a subculture of speculation and innovation on purely digital assets.

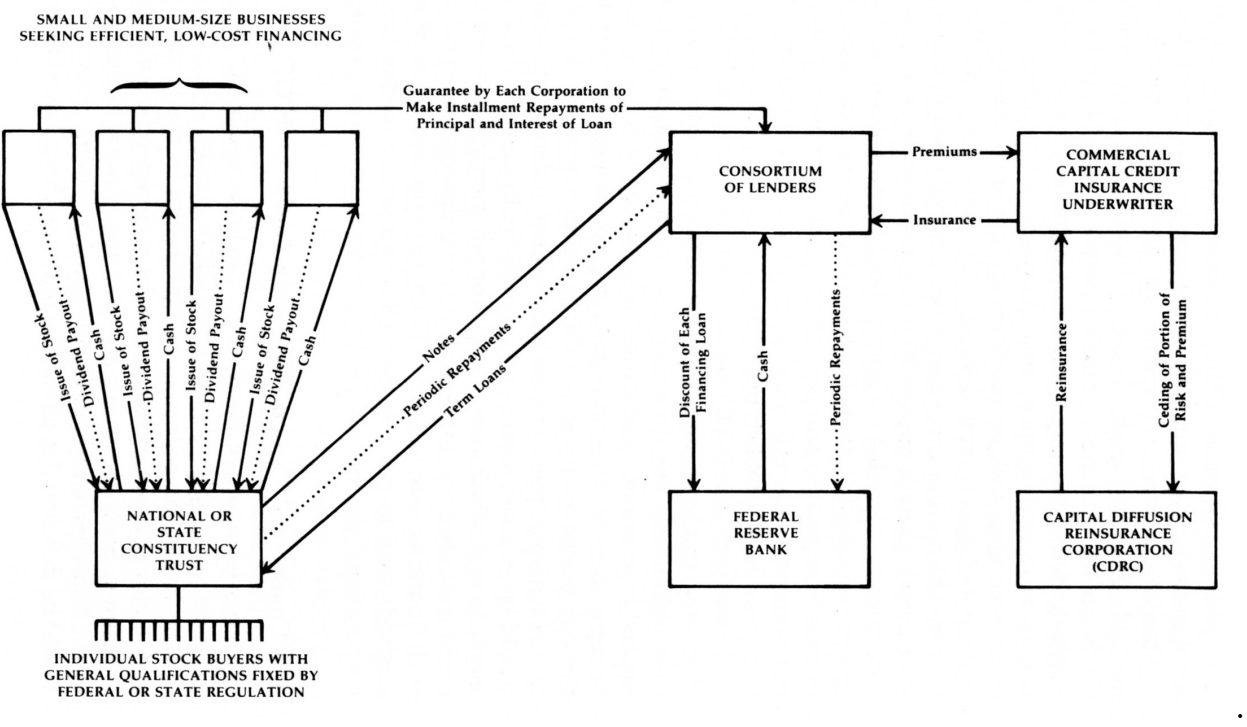

Figure 3: Individual Capital Ownership Plan (ICOP) in Kelso and Kelso (1986)

Kelsoism similarly seeks to universalize the investor class. But rather than through one-off engagements by individuals, Kelsoist models approach the task as a structural and collective endeavor. The General Stock Ownership Plan (GSOP), the Individual Capital Ownership Plan (ICOP, see Figure 3), and the Commercial Capital Ownership Plan (COMCOP) described in Kelso and Kelso (1986) would enable under-capitalized people to undertake leveraged investments in pre-vetted enterprises. Unlike the ESOP or the CSOP, these may not arise from direct transactional relationships with the enterprises in question, although eligible investors might be expected to have at least some stakeholder relationship.

For instance, a GSOP structure could be employed for the development of community assets for which stakeholder accountability can help contribute to the asset's success. Consider, for instance, if residents of a neighborhood secured GSOP financing to develop and own a fiber-to-the-home broadband network. Their company could next invest in "smart city" technology, and the neighbors would ensure that the data collection and machine-learning systems would operate in ways accountable to them, both financially and 
ethically. A further application might be a modification of the proposed "community information district" model (Galperin 2017), which envisions funding local journalism and information systems through a taxation model akin to a library district; rather than using taxation, a GSOP could secure financing for equity investments in local news organizations, the returns on which could in turn remain among the community's citizen-investors.

The ISCOP, which would allow individuals to make leveraged investments in the stock of vetted businesses - particularly ones too small to participate in public stock markets - could be a means of escalating and mainstreaming the still-marginal market for "equity crowdfunding." Loan guarantees, combined with platform marketplaces (a growing number of which are already in operation), could enable community members to invest significantly in businesses without necessarily having the consistency of the relationship presumed by the CSOP. By making leveraged investments, people of modest means would be risking little or none of their own money.

Kelsoist tools could enable fledgling markets like equity crowdfunding to reach their potential, inviting many more people to adopt the occupation of capital work. In the Kelsoist vision, this would mean access to a growing share of non-labor income and the opportunity to engage in strategic thinking about how best to nourish the economy in their communities.

\section{Post-work}

The aforementioned presidential campaign of Andrew Yang is but one sign of swelling interest in further universalizing non-labor income, particularly in the context of the digitizing economy. Strenuous debates persist about whether increased automation inevitably leads to the singularity of "technological unemployment" or not, but to expect inevitability is to misstate the question. Kelsoism, along with some recent advocates of universal basic income, stresses that society should make an active choice to embrace automation in a way that delivers not merely new kinds of work but livelihoods that liberate more time for leisure (Kelso and Kelso 1968, 1986).

In contrast to typical prescriptions for universal basic income (e.g., Van Parijs and Vanderborght 2017; Yang 2018), however, Kelsoism proposes not a redistributive cash transfer - assessed, for instance, by a value-added tax or a financial transaction tax on capital markets - but a policy-aided expansion of access to capital ownership. One structural benefit for this kind of approach is that, as more people can shift toward less dependence on 
labor income, they remain integrally involved as direct stakeholders in the productive economy. In contrast, taxation-based cash transfers may lead to a growing gulf between the capital-holding few, who orchestrate the productive flows of the economy, and the many, who become relegated to a cycle of consumer purchasing and redistributive transfers.

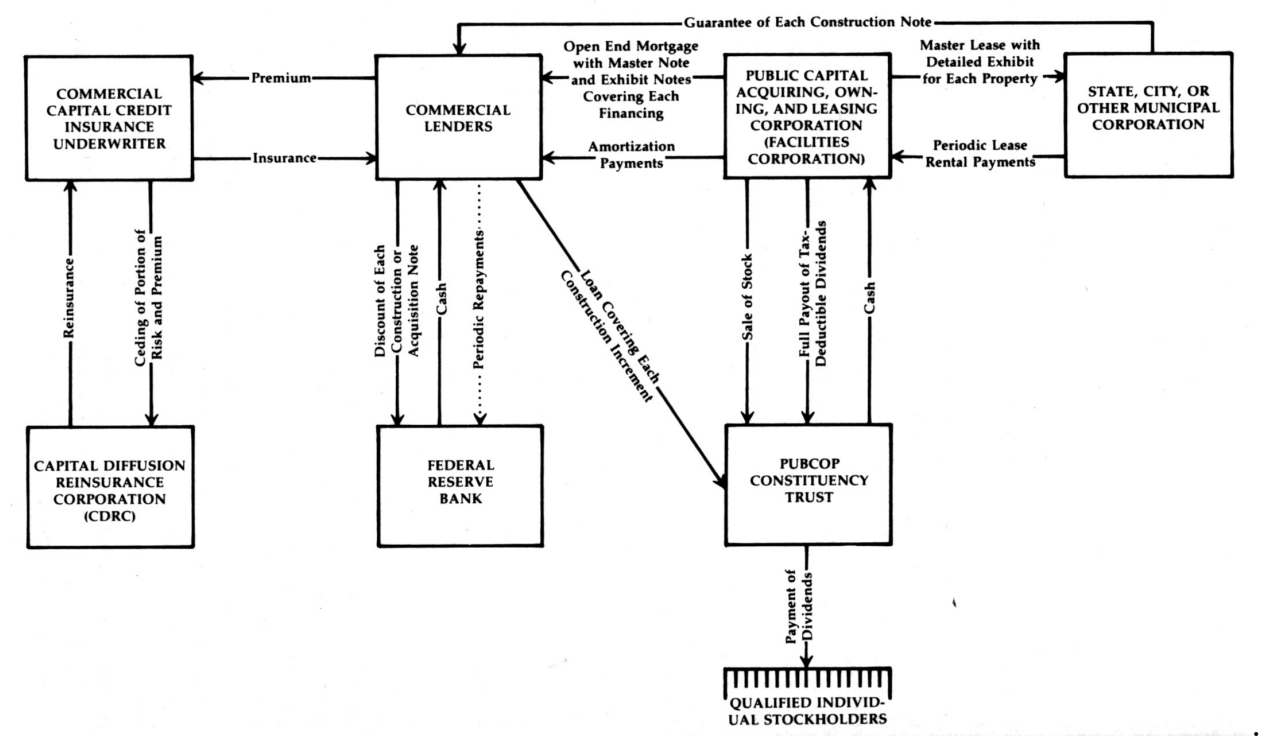

Figure 4: Public Stock Ownership Plan (PUBCOP) in Kelso and Kelso (1986)

The basis for universal dividends might be found in Kelso and Kelso (1986)'s PUBCOP proposal (Figure 4), which facilitates privatization of public assets through citizen investment, or Hockett (2007)'s proposal for "RentSOPs," which distribute incomes from the private use of public assets. The latter, especially, resembles the Alaska Permanent Fund, which US universal basic income advocates frequently use as a template. (Louis Kelso took part in legislative efforts for several such regional schemes, recounted in Speiser (1977).) Kelsoist models also bear resemblances to financing mechanisms proposed in Matt Bruenig (2018)'s sketch of a federal "Social Wealth Fund for America." But mature Kelsoism does not rely on any one mechanism, and it eschews direct, governmental entitlement programs. Its purpose is to furnish an array of diverse capital strategies through which people use asset ownership to withdraw from dependence on labor and assume the time-liberating opportunity of capital work. 


\section{Commodity or commons?}

We have seen that some critics, especially those less enamored with capitalism than Louis Kelso, have feared that ESOP-like schemes lead only to further commodification of life, rather than a more strenuously democratic economy (Ellerman 1985; Murphy 2005). Turning more people into capital owners, that is, further turns society as a whole toward profit-seeking at all costs, above other conceptions of what constitutes the common good. This critique echoes older concerns, such as consumer co-op advocate Beatrice Webb (1904)'s contention that worker-owned cooperatives would replace exploitation of the public by capitalists with exploitation of the public by worker-owners.

In reality, the legacy of the cooperative movement, including worker co-ops, has been mixed in this regard (Schneider 2018a). While some co-op businesses seem indistinguishable from other businesses, or worse, others have succeeded in using economics to make space for genuine democratic politics within themoften in ways that only aid in economic flourishing. The same might be said for the legacy of ESOPs, many of which have become exemplary employers and community assets, especially when the ESOP aligns with participatory management and a strong sense of collective purpose (Kelly 2012; Blasi, Kruse, and Freeman 2018). Alongside some conventional economic analysis, theories of common-pool resource management (Ostrom 1990) predict that a strong sense of shared ownership, properly governed, can produce attractive economic and social effects.

In the implementation of a Kelsoist program, various choices might prioritize value maximization, economic democracy, or social benefits, respectively. For instance, rather than the retirement-plan trust of the ESOP, future SOPs could employ perpetual-purpose trusts (Michael 2017; Schneider 2020). They might explicitly include cooperative-like governance, as some recent ESOPs have done (Staubus 2017). Following Canadian examples, they might employ cooperatives, rather than trusts, as the stock-holding entity (Bhowmik 1994; Ellerman 2019). Through benefit corporation status, companies can also enshrine an overriding social purpose alongside their SOP ownership. And forms of pre-determined co-determination, such as among employees of many European corporations, could accompany any degree of ownership stake. Emerging governance mechanisms, such as liquid democracy (Hardt and Lopes 2015) and quadratic voting (Posner and Weyl 2018), offer new means to facilitate large-scale community governance. ${ }^{4}$ With such an expanded

\footnotetext{
${ }^{4}$ Liquid democracy is a delegative system that, in a rolling referendum process, allows voters to delegate votes to people they deem to have more time and expertise; quadratic
} 
menu of options, Kelsoism could not merely extend capitalism but transform it beyond recognition.

\section{Kelsoism as a political strategy}

When I asked her about the challenge of advancing Kelsoist goals, Patricia Hetter Kelso confessed, "Louis and I were not astute" ("Interview" 2019). She was surely selling herself and her husband short for their unlikely and nearly single-handed achievements with the ESOP. These achievements, despite the unfinished work she sees before her, reveal Kelsoism as not merely a set of abstract objectives but a strategy for achieving them. This strategic legacy need not constrain the possibilities of future Kelsoist efforts, but it should at least be considered at the outset.

Speiser (1977) quotes Louis Kelso as having told him, when they met at the Waldorf Astoria hotel in New York, "This won't be a grubby revolution. Nobody will have to eat worms!" (40) For better or worse, Kelso made good on the promise. The decades-long process of advancing the ESOP and other proposals involved no noisy street demonstrations or populist uprisings. It was a campaign of persuasion, aimed at the most elite possible audiences. Rather than spinning up new bureaucracies on the model of a New Deal or Great Society, Kelsoism seeks targeted interventions in the existing system - a policy change here, a legal innovation there, each orchestrated to reinforce one another. These interventions should also be win-win for all stakeholders to the extent possible. Kelso's writings reject anything that smacks of redistribution or outright power transfers. Kelsoism aims to extend power and wealth to where they are lacking rather than disturb the bastions where they presently lie. It aspires to a logic of earning rather than receiving.

The win-win approach extends not just to the public policy design but to the private implementation. "When I invented the ESOP, I started a whole new industry," Kelso told Bill Moyers (1990). To an extent this is true. As a lawyer, he had a knack for designing mechanisms that would generate revenue for people like him, in turn offering such professionals an incentive to promote the mechanisms to their clients. After developing the ESOP, he turned it into a business for himself. The online Provider Directory of the National Center for Employee Ownership currently lists over 300 ESOP service professionals in the United States, including law firms, banks, accountants, and myriad consultants.

voting is an efficient mechanism for weighing diverse levels of voter commitment. 
A further outgrowth of Kelsoism's win-win minimalism is its bipartisanship. Just as Kelso sought out both Republican and Democratic politicians, employee ownership through ESOPs has come to represent a quiet consensus across the US political spectrum, even in the most polarized of times. The 2016 platforms of both the Republican and Democratic parties included support for employee ownership - albeit with distinct rationales; Republican Rep. Paul Ryan and democratic-socialist Sen. Bernie Sanders have been longstanding supporters of ESOPs, despite little else in common between them. Congress passed the Main Street Employee Ownership Act in 2018, the most significant piece of related legislation in recent years, with nearly downthe-middle bipartisan cosponsors. It is hard to think of another "revolution" that is so politically ambidextrous.

A Kelsoist strategy applied to the platform economy would need to invite in a new set of stakeholders, including some who might not otherwise likely see eye to eye. For instance, it might offer new options for growth financing or liquidity for existing platform owners, such as founders and venture-capital investors. Selling their stake to platform users, workers, or other "new capitalist" stakeholders could be an alternative to conventional liquidity events like a public offering or acquisition. Adding new exit options could have effects across the entrepreneurial ecosystem, enabling investors to finance a wider range of startups and inspiring new kinds of business models attuned specifically toward cultivating strong stakeholder relationships with a company's future capital workers.

New ownership and financing options might be most eagerly embraced among the entrepreneurs who have been neglected by current startup communities, such as participants in the Zebras Unite network, led largely by founders who are women and people of color (Griffith 2019). Having faced barriers to capital access by the predominately White and male investor class, such entrepreneurs could welcome opportunities for raising capital through their under-capitalized users and communities. In doing, they can find common cause with organizations that advocate for social justice in the digital economy, such as Allied Media Projects, Color of Change, the Electronic Frontier Foundation, Free Press, and Mozilla.

A Kelsoist strategy is not likely to succeed, finally, without the support of policymakers, who alone can enact the tax arrangements, regulatory guardrails, and financing apparatus that will lean the existing system away from its bias toward concentrated ownership. Digital Kelsoism could be as politically ambidextrous as the ESOP has been. It should appeal to politicians 
looking to impose reforms on the mounting excesses of the tech industry, by adding a dose of economic democracy alongside antitrust enforcement, privacy protections, and labor rights. But Kelsoism can appeal also to politicians most eager to ensure the flourishing of business, as it would introduce attractive new techniques for financing corporate growth.

Future Kelsoist strategies could improve on the ESOP legacy by ensuring that any particular implementations of policy or business design do not become substitutes for the vision as a whole. This means continuing to articulate that vision alongside advocacy for particular models. While Kelsoist techniques are necessarily partial and finite, Kelsoism itself might act more like an everbeckoning horizon, calling adherents to further expanding and deepening economic democracy.

Measured by the scale of intervention (a series of targeted adjustments to existing legal frameworks) and the resulting effect (millions of employee owners across diverse firms), Kelsoist strategy in the form of the ESOP has been uncommonly effective, and a renewed Kelsoism could have even greater effects today. However, Jedidiah Kroncke (2018) may be right to question the adequacy of "the private, gradual and non-conflictual transformation that Kelso imagined" (320). To unseat entrenched power, he argues, the powerful will on some level need to be confronted and defeated: "No genius of pure legal innovation can escape politics."

\section{Conclusion: Capital work and citizenship}

In societies where most people's economic lives consist of producing widgets through labor and buying them as consumers, the abstractions of Kelsoist capital work might seem remote. Even now, no more than half of US households own any company stock, directly or indirectly (Wolff 2017). It is thus not surprising that, among the Kelsos' various plans, the ESOP was the first to take hold in US law and business practice. But in societies where economic value increasingly changes hands virtually, where many of our closest relationships to platform companies occur at little or no monetary cost, Kelsoism may hold fresh attractions. When key stakeholder relationships are no longer so transactional, when economic processes are ever more autonomous and automated, capital becomes the critical means remaining for popular economic participation. And as the social significance of platforms grows, control over them may even become a prerequisite for full citizenship. 
In the wake of the 2016 US election, and the controversies surrounding Facebook's role in it, CEO Mark Zuckerberg issued a reflective essay titled "Building Global Community." In it, among other things, he envisioned ways that Facebook could not only address its shortcomings but contribute toward shaping the next stage of human society as a whole. He suggested that a step toward the new social contracts would be cultivating participatory governance within Facebook itself. "Building an inclusive global community," for instance, "requires establishing a new process for citizens worldwide to participate in community governance." (Zuckerberg 2017)

It's notable that he wrote of "citizens" rather than "users" - as if he were beginning to understand Facebook as not just a company but a polity. The essay concludes with a quotation from Abraham Lincoln. At the time, speculation abounded that Zuckerberg might be planning a run for president, but some pointed out that running Facebook might already be more powerful than that office. "In a lot of ways Facebook is more like a government than a traditional company," Zuckerberg has reportedly said (Foer 2017).

Two years later, after ever-mounting scrutiny and criticism of the platform, he abandoned this vision of "global community" for a more atomizing platform society based on private, encrypted messaging (Zuckerberg 2019). Yet the earlier Zuckerberg was likely right about at least one thing: networked platforms have the capacity to reshape the social and political order on a global scale. And since platforms are typically owned and governed through corporations, the manner in which these corporations are owned and governed should be of pressing importance. While much debate around these platforms has focused on external regulation of their behaviors, a Kelsoist approach ${ }^{5}$ could take on platform ownership and governance from the inside. It could also, as Zuckerberg implies, contribute to a redefinition of global citizenship.

The ESOP as currently instantiated has been a phenomenon bounded within national borders as an aspect of US law related to employment and retirement benefits. Future Kelsoist structures might be less constrained, especially if they are attuned to the intrinsically transnational nature of the platform economy. If corporate platforms begin competing with or replacing nation-states as arbiters of such things as identity, reputation, and monetary transactions, they may become arbiters for new equivalents of citizenship. And just as citizenship in democratic societies should involve a right to co-govern, real citizenship on corporate platforms might come to mean a right to co-own.

\footnotetext{
${ }^{5}$ Kelsoism can be regarded as a strategic accompaniment to platform cooperativism (Schneider 2018b), which takes root in the cooperative tradition specifically.
} 
This ownership can be more dynamic, pluralistic, and border-crossing than national citizenship is today. But to prevent capital-based citizenship from reiterating the petty aristocracy that now owns the platforms, ownershipexpanding Kelsoist techniques are needed. Being a user may need to become intertwined with democratized capital work.

This will not be a universally welcome prospect. Capital ownership comes with a checkered pedigree, from its associations with the Atlantic slave trade (Baucom 2005) to the short-termist ills of shareholder primacy (Stout 2013). Just as twentieth-century policies to expand home-ownership in the United States resulted in such practices as discriminatory "red lining," twentyfirst-century platforms exhibit signs of algorithmic discrimination (Noble 2018); Kelsoist plans could further entrench such inequalities, intentionally or otherwise. Yet making capital ownership more widespread could serve as what André Gorz (1968) called a "non-reformist reform"- transforming, that is, the meaning of capital ownership by adjusting the terms by which it occurs. In the ESOP experience, one can find companies that appear to be so transformed through co-ownership and participatory management, while others appear to advance a familiar capitalist logic. The prognosis is inconclusive, even 14 million employee owners later.

I hope this essay serves to whet more appetites for the study of Kelsoismas not simply an eccentric idea that culminated in the ESOP but as a broader horizon of economic democracy toward which the ESOP served as a preliminary experiment. This horizon may be especially relevant for a time when economic life increasingly takes place across virtual terrains, when the returns to labor fall chronically behind the gains of capital, and when that capital is in danger of concentrating to ever more feudal levels. While the ESOP is an arrangement for compensating labor, full Kelsoism envisions a world with less need for labor, in which people retain their participation in production ever more through their creative, leisurely capital work - and benefit through their capital gains. If the capitalist corporation is to remain a basic economic unit, and if the capitalist oligarchy's raids on political democracy are to be counteracted, the Kelsoist demand that citizenship should entail ownership deserves further consideration. Otherwise, many people may experience the ever greater marginalization Kelso and Kelso (1986) feared in a society that

denies the capitalless majority of citizens their right to be productive - a right dependent in our industrial age upon effective opportunity to acquire, own, and protect capital. 


\section{References}

Alvaredo, Facundo, Anthony B. Atkinson, Thomas Piketty, and Emmanuel Saez. 2013. "The Top 1 Percent in International and Historical Perspective." Journal of Economic Perspectives 27 (3): 3-20. https://doi.org/10.1257/jep. 27.3.3.

Ashford, Robert H. A. 1990-1991. "The Binary Economics of Louis Kelso: The Promise of Universal Capitalism." Rutgers Law Journal 22: 3. https://heinonline.org/HOL/Page?handle=hein.journals/rutlj22\&id=15\& $\operatorname{div}=\&$ collection $=$.

Baucom, Ian. 2005. Specters of the Atlantic: Finance Capital, Slavery, and the Philosophy of History. Duke University Press. https://doi.org/10.1215/ 9780822387022 .

Bhowmik, Sharit K. 1994. "Workers as Shareholders: Case for Closer Examination." Economic and Political Weekly 29 (40): 2580-2.

Blasi, Joseph, Douglas Kruse, and Richard B. Freeman. 2018. "Broad-Based Employee Stock Ownership and Profit Sharing: History, Evidence, and Policy Implications." Journal of Participation and Employee Ownership 1 (1): 38-60. https://doi.org/10.1108/JPEO-02-2018-0001.

Boggs, James. 1963. The American Revolution: Pages from a Negro Worker's Notebook. New York: Monthly Review Press. http://www.historyisaweapon. com/defcon1/amreboggs.html.

Bruenig, Matt. 2018. "Social Wealth Fund for America." People's Policy Project. 2018. https://peoplespolicyproject.org/projects/social-wealth-fund.

Brynjolfsson, Erik, and Andrew McAfee. 2016. The Second Machine Age: Work, Progress, and Prosperity in a Time of Brilliant Technologies. New York: W. W. Norton \& Company.

Cramton, Peter, Hamid Mehran, and Joseph S. Tracy. 2008. "ESOP Fables: The Impact of Employee Stock Ownership Plans on Labor Disputes." FRB of New York Staff Report 347. https://papers.ssrn.com/abstract=1266717.

Ellerman, David. 2015. "Comments on Robert Hockett's Papers." Unpublished commentary. Unpublished commentary.

. 2019. "A Generic Model for Employee Stock Ownership Plans." Working Paper. Ljubljana, Slovenia: Institute for Economic Democracy. 
Ellerman, David P. 1985. "ESOPs \& CO-OPs: Worker Capitalism \& Worker Democracy." Labor Research Review 1 (6).

Eubanks, Virginia. 2018. Automating Inequality: How High-Tech Tools Profile, Police, and Punish the Poor. St. Martin's Press. http://books. google.com?id=pn4pDwAAQBAJ.

Foer, Franklin. 2017. "Facebook's War on Free Will." The Guardian: Technology, September 19, 2017. https://www.theguardian.com/technology/ 2017/sep/19/facebooks-war-on-free-will.

Galperin, Simon. 2017. “Journalism Is a Public Service. Why Don't We Fund It Like One?" Columbia Journalism Review, July 19, 2017. https://www.cjr.org/united_states_project/local-news-special-servicecommunity-information-districts.php.

Gorz, André. 1968. Strategy for Labor : A Radical Proposal. Boston : Beacon Press. http://archive.org/details/strategyforlabor00gorz.

Griffith, Erin. 2019. "More Start-Ups Have an Unfamiliar Message for Venture Capitalists: Get Lost." The New York Times, January 13, 2019. https://www.nytimes.com/2019/01/11/technology/start-ups-rejectingventure-capital.html.

Hardt, Steve, and Lia C. R. Lopes. 2015. "Google Votes: A Liquid Democracy Experiment on a Corporate Social Network." Technical Disclosure Commons, Defensive Publications Series, June. https://www.tdcommons.org/dpubs series $/ 79$.

Hockett, Robert. 2007. "What Kinds of Stock Ownership Plans Should There Be - of ESOPs, Other SOPs, and Ownership Societies." Cornell Law Review 92 (5): 865. https://scholarship.law.cornell.edu/clr/vol92/iss5/1.

"Interview." 2019.

Karabarbounis, Loukas, and Brent Neiman. 2013. "The Global Decline of the Labor Share." Working Paper 19136. National Bureau of Economic Research. https://doi.org/10.3386/w19136.

Kelly, Marjorie. 2012. Owning Our Future: The Emerging Ownership Revolution. San Francisco: Berrett-Koehler Publishers. http://books.google. com?id=TaN1DPwsheAC.

Kelso, Louis O. 1984. "Labor's Untapped Wealth." Air Line Pilot, October 1984 . 
Kelso, Louis O., and Mortimer J. Adler. 1958. The Capitalist Manifesto. New York: Random House. http://books.google.com?id=WRj7DQAAQBAJ.

- 1961. The New Capitalists: A Proposal to Free Economic Growth from the Slavery of Savings. New York: Random House.

Kelso, Louis O., and Patricia Hetter Kelso. 1982. "The Right to Be Productive." The Financial Planner, August 1982.

. 1986. Democracy and Economic Power: Extending the ESOP Revolution Through Binary Economics. Cambridge, MA: Ballinger Publishing. http://books.google.com?id=_R5XDQAAQBAJ.

—. 1989. "Why I Invented the ESOP LBO." Leaders, October 1989. http://kelsoinstitute.org/louiskelso/literary-legacy/why-i-invented-theesop-lbo/.

Kelso, Louis O, and Patricia Hetter Kelso. 1968. How to Turn Eighty Million Workers into Capitalists on Borrowed Money. New York: Random House.

Khan, Lina M. 2017. "Amazon's Antitrust Paradox." Yale Law Review 126 (3): 564-907. https://www.yalelawjournal.org/note/amazons-antitrustparadox.

Kroncke, Jedidiah J. 2018. "ESOPs and the Limits of Fractionalized Ownership." University of Chicago Legal Forum 2017 (12): 40. https://legalforum.uchicago.edu/publication/esops-and-limits-fractionalized-ownership.

Levin, William R. 1985-1986. "The False Promise of Worker Capitalism: Congress and the Leveraged Employee Stock Ownership Plan Note." Yale Law Journal 95: 148-73. https://heinonline.org/HOL/P?h=hein.journals/ ylr95\&i $=165$.

McDonald, Sean. 2019. "Reclaiming Data Trusts." Centre for International Governance Innovation. March 5, 2019. https://www.cigionline.org/articles/ reclaiming-data-trusts.

McElrath, Roger G., and Richard L. Rowan. 1992. "The American Labor Movement and Employee Ownership: Objections to and Uses of Employee Stock Ownership Plans." Journal of Labor Research 13 (1): 99-119. https: //doi.org/10.1007/BF02685454.

Michael, Christopher. 2017. "The Employee Ownership Trust, an ESOP Alternative." Probate $\&$ Property 31 (1): 42-47. 
Mishel, Lawrence. 2018. "Uber and the Labor Market: Uber Drivers' Compensation, Wages, and the Scale of Uber and the Gig Economy." Washington, D.C.: Economic Policy Institute. https://www.epi.org/publication/uber-and-the-labor-market-uber-driverscompensation-wages-and-the-scale-of-uber-and-the-gig-economy/.

Moyers, Bill. 1990. "Louis Kelso: Capitalist." In A World of Ideas II: Public Opinions from Private Citizens, edited by Andie Tucher. New York: Doubleday.

Murphy, Michael E. 2005. "The ESOP at Thirty: A Democratic Perspective." Willamette Law Review 41: 655-706. https://heinonline.org/HOL/P?h=hein. journals $/$ willr $41 \& \mathrm{i}=670$.

National Center for Employee Ownership. n.d. "ESOPs by the Numbers." Accessed March 16, 2019. https://www.nceo.org/articles/esops-bythe-numbers.

Noble, Safiya Umoja. 2018. Algorithms of Oppression: How Search Engines Reinforce Racism. New York: NYU Press.

Novak, Michael. 1984. "Saving Distributism." The Chesterton Review 10 (1). https://doi.org/10.5840/chesterton19841015.

Ostrom, Elinor. 1990. Governing the Commons: The Evolution of Institutions for Collective Action. Cambridge, UK: Cambridge University Press.

Pasquale, Frank. 2015. The Black Box Society. Cambridge, MA: Harvard University Press.

Posner, Eric A., and E. Glen Weyl. 2018. Radical Markets: Uprooting Capitalism and Democracy for a Just Society. Princeton: Princeton University Press. http://books.google.com?id=xJg8DwAAQBAJ.

Posner, Richard. 2006. "Summers V. State Street Bank \& Trust Company and UAL Company ESOP Committee." United States Court of Appeals, Seventh Circuit. https://openjurist.org/453/f3d/404.

— 2007. "The Economics of ESOPs." The Becker-Posner Blog. April 8, 2007. https://www.becker-posner-blog.com/2007/04/the-economics-ofesops--posners-comment.html.

Samuelson, Paul A. 1977. "Thoughts on Profit Sharing." Zeitschrift Fur Die Gesamte Staatswissenschaft, 9-18. 
Schneider, Nathan. 2018a. Everything for Everyone: The Radical Tradition That Is Shaping the Next Economy. New York: Nation Books.

- 2018b. "An Internet of Ownership: Democratic Design for the Online Economy." The Sociological Review 66 (2).

—. 2020. "User Trusts: Broad-Based Ownership for Online Platforms." Informatik Spektrum, no. 43: 9-14. https://osf.io/puy5d/.

Scholz, Trebor. 2017. Uberworked and Underpaid: How Workers Are Disrupting the Digital Economy. New York: John Wiley \& Sons. http: //books.google.com?id=0pNNDwAAQBAJ.

Schor, Juliet. 2014. "Debating the Sharing Economy." Great Transition Initiative.

Speiser, Stuart M. 1977. A Piece of the Action: A Plan to Provide Every Family with a \$100,000 Stake in the Economy. New York: Van Nostrand Reinhold Co.

Srnicek, Nick, and Alex Williams. 2015. Inventing the Future: Postcapitalism and a World Without Work. Brooklyn, NY: Verso.

Standing, Guy. 2011. The Precariat: The New Dangerous Class. London: Bloomsbury Academic.

Staubus, Martin. 2017. "The ESOP-Erative." Fifty by Fifty: Employee Ownership News. August 17, 2017. https://medium.com/fifty-by-fifty/theesop-erative-daaa98c1174f.

Stout, Lynn A. 2013. "On the Rise of Shareholder Primacy, Signs of Its Fall, and the Return of Managerialism (in the Closet)." Seattle University Law Review 36: 1169.

Talbot, David A., Kira Hope Hessekiel, and Danielle Leah Kehl. 2017. "Community-Owned Fiber Networks: Value Leaders in America." Berkman Klein Center for Internet \& Society Research Publication. Harvard University. https://dash.harvard.edu/handle/1/34623859.

Unknown author. 1970. "The Man Who Would Make Everybody Richer." Time, June 29, 1970. http://content.time.com/time/magazine/article/0, 9171,878872,00.html.

Vaheesan, Sandeep, and Nathan Schneider. 2019. "Cooperative Enterprise as an Antimonopoly Strategy." Penn State Law Review 124 (1). 
http://www.pennstatelawreview.org/print-issues/cooperative-enterpriseas-an-antimonopoly-strategy/.

Van Parijs, Philippe, and Yannick Vanderborght. 2017. Basic Income: A Radical Proposal for a Free Society and a Sane Economy. Cambridge, MA: Harvard University Press.

Webb, Beatrice Potter. 1904. The Co-Operative Movement in Great Britain. London: S. Sonnenschein \& co. http://archive.org/details/ cu31924013851039.

Weitzman, Martin L. 1984. The Share Economy: Conquering Stagflation. Cambridge, Mass: Harvard University Press.

Wolff, Edward N. 2017. "Household Wealth Trends in the United States, 1962 to 2016: Has Middle Class Wealth Recovered?" Working Paper 24085. National Bureau of Economic Research. https://doi.org/10.3386/w24085.

Yang, Andrew. 2018. The War on Normal People: The Truth About America's Disappearing Jobs and Why Universal Basic Income Is Our Future. New York: Hachette.

Zuboff, Shoshana. 2019. The Age of Surveillance Capitalism: The Fight for a Human Future at the New Frontier of Power. New York: PublicAffairs.

Zuckerberg, Mark. 2017. "Building Global Community." Facebook. February 16, 2017. https://www.facebook.com/notes/mark-zuckerberg/buildingglobal-community/10154544292806634.

. 2019. "A Privacy-Focused Vision for Social Networking." Facebook. March 6, 2019. https://www.facebook.com/notes/mark-zuckerberg/aprivacy-focused-vision-for-social-networking/10156700570096634/. 